\title{
Small Intestinal Non-Hodgkin Lymphoma
}

National Cancer Institute

\section{Source}

National Cancer Institute. Small Intestinal Non-Hodgkin Lymphoma. NCI Thesaurus.

Code C7231.

A B-cell or T-cell non-Hodgkin lymphoma that arises from the small intestine.

Representative examples of B-cell non-Hodgkin lymphoma include diffuse large B-cell

lymphoma, MALT lymphoma, alpha heavy chain disease/immunoproliferative small

intestinal disease, Burkitt lymphoma, follicular lymphoma, and mantle cell lymphoma. The

T-cell non-Hodgkin lymphomas are the enteropathy-associated T-cell lymphoma and the monomorphic CD56 positive intestinal T-cell lymphoma. 